\title{
"Gegen eine Zeit, die Helden braucht, richten wir nichts aus": Honour as Moral Blindness in Christa Wolf's Kassandra 1
}

\author{
Alyth Grant
}

"Die Ehre des Soldaten liegt im bedingungslosen Einsatz seiner Person für Volk und Vaterland bis zur Opferung seines Lebens." Thus writes Hermann Pongs, "im Felde" in 1942 and continues:

Wunderbare Klarheit geht von dem einfachen Satz aus, der das zweite Gebot der "Pflichten des deutschen Soldaten" zusammenfaßt. Ein hartes preußisches : "Du sollst" spricht sich aus. Doch wird von dem klaren Strahl der Pflicht nicht nur Wille und Bewußtsein durchleuchtet, auch die tiefere Landschaft der Seele, die in den Muttergrund von Volk und Vaterland eingewachsen ist. Und wir spüren in der letzten Steigerung: "bis zur Opferung des Lebens" mehr als das eiserne Gebot, wir spüren jenen Schauer der Entschlossenheit zum Tod, der aus dem Opfer, aus der Freiwilligkeit kommt, indem im Drang nach Ehre, im Drang zum Tode die Existenz sich ihrer Tiefe und Freiheit wie nie gewiß wird. ${ }^{2}$

Such was the concept of honour current during Christa Wolf's formative years. The willingness to make the supreme sacrifice, found not only in the German tradition of soldierly honour, is here exalted to a pseudo religious status by the parallel with Christ's words: "For whosoever will save his life shall lose it: and whosoever will lose his life for my sake shall find it." (Matthew 17, 25) For the soldier, however, it is honour rather than life that is to be had by making the ultimate sacrifice. The "Drang nach Ehre" is identical with the "Drang zum Tode". Honour for the soldier is not a reputation achieved by the living out of moral values; rather it is a form of glory attained by his willingness to sacrifice his life for what is seen as the greater good, "Volk und Vaterland". To this extent "Soldatenehre" as defined by Pongs bears some similarity to "ritterliche Ehre" as defined by Friedrich Maurer. Maurer sees mediaeval "êre" as distinct from the ethical value "honestum" as used by Cicero:

Einerseits [. . .] ist der Besitz der ere, des öffentlichen Ansehens, Voraussetzung für die ritterliche Existenz, für die Ausübung und Darstellung der Werte des honestum. Anderseits ist aber auch der Besitz, das Vorhandensein dieser Werte und ihre Achtung die Voraussetzung für die ere, die öffentliche Anerkennung $[. . .]^{3}$ 
But while Maurer here emphasizes the close interaction between the external "öffentliche Anerkennung" and the inner moral values, Pongs's definition of "Soldatenehre", in its emphasis on self-sacrifice to the exclusion of all other values, places little value on the integrity of the individual. It is this distortion that Christa Wolf sees as inherent in the European heroic tradition and she shows in Kassandra that its consequence is inner conflict and self-alienation for the individual, and ultimately the self-annihilation of humanity.

Christa Wolf, in opposition to the official doctrine of the DDR, has not denied the influence of the immediate literary tradition from which she stems. Rather, in Kindheitsmuster she sought to come to terms with it, by confronting on behalf of her fellow citizens her own past, examining the formative influences on her childhood self and the beliefs once so vigorously held. In the process of reactivating the layers of memory she makes apparent the role played consciously and subconsciously by the experiencing individual in repressing unwanted memories. Thus one fails to "see" because one does not wish to see. Thus she denies that the individual is the mere plaything of history or the gods. Further, by integrating the process of recall into the narrative fabric she reveals that the primary factor in the selectiveness and repression of memory is fear, the fear of encountering the unpleasant truths of oneself. "Verstellung" is preferred to self-knowledge, since it ensures the approval of the world and the sense of belonging. But the reward for passing through the centre of that fear, for putting aside all inclination towards "Verstellung", for being absolutely honest, was an understanding and at least a tentative acceptance of herself, opening the possibility of beginning to heal the breach between the personae of 1945 and 1949 .

While in Kindheitsmuster this form of the "difficulty of saying I" is a specifically German problem, in Kassandra Wolf shows that the influence of the European tradition on modern thought, particularly in the virtue it attributes to soldierly honour, has a wider and on-going significance. In the third lecture of the Voraussetzungen einer Erzählung:Kassandra Wolf indicates how basic to European thought and tradition she considers soldierly honour to be. At this point she is reflecting on the theory of the historian Schachermayer as to the genesis and function of the heroic epic as an instrument for recording the history of peoples which had no written language. In the epic the number, variety, complexity and confusion of actual figures and events is distilled to a few vivid ideal figures and symbolic acts in a greatly contracted time span. Wolf comments:

Was bedeutet diese Erfahrung für eine Literatur, die keine großen lebenskrättigen 
Idealgestalten mehr schaffen, keine zusammenhängenden - durch Krieg und Mord und Totschlag und die dazu fälligen Heldentaten zusammenhängenden Geschichten mehr erzählen will? Welche Art von Gedächtnis verlangt und unterstützt die Prosa der Virginia Woolf? Warum sollte das Gehirn, das doch oft mit einem Netzwerk verglichen wird, die Erzählung einer linearen Fabel besser "behalten" können als ein erzählerisches Netzwerk? Wie sonst könnte ein Autor gegen die Gewohnheit angehen (die den Anforderungen der Zeit nicht mehr entspricht), Geschichte als Heldengeschichte zu erinnern? Die Helden sind auswechselbar, das Muster bleibt. Auf diesem Muster entwickelte sich die Ästhetik. (V. 117)

She thus places in doubt the validity of accepted aesthetic criteria as appropriate to the needs of the present day. This scepticism towards the efficacy of chronological narrative based on cause and effect or of "Idealgestalten" as literary means for approaching reality or truth is familiar to readers of Wolf's earlier work, but in Kassandra she links it specifically with a rejection of the values and patterns of behaviour associated with the heroic tradition. Kassandra ultimately rejects Aineias's insistence that she escape with him to found a new Troy, on the grounds that to succeed in doing so, he will have to be a hero and his actions therefore will continue to be determined, through the patterns of action and reaction, by "die neuen Herren":

Es war ja klar: Allen, die überlebten, würden die neuen Herren ihr Gesetz diktieren. Die Erde war nicht groß genug, ihnen zu entgehn. Du, Aineias, hattest keine Wahl: Ein paar hundert Leute mußtest du dem Tod entreißen. Du warst ihr Anführer. Bald, sehr bald wirst du ein Held sein müssen.

Ja! hast du gerufen. Und? - An deinen Augen sah ich, du hattest mich begriffen. Einen Helden kann ich nicht lieben. Deine Verwandlung in ein Standbild will ich nicht erleben. (K. 156)

What Wolf offers in place of the heroic tradition is at one with the tenor of her earlier work. It is still utopian but the vision that is communicated is coloured by the irony of Kassandra's fate: to know or proclaim the truth, but not to be believed. It involves the rejection of the heroic virtues in that the assumptions which make them necessary are exposed and discredited. It involves replacing "Soldatenehre" with "Ehrlichkeit", the courage of the battlefield with the courage to see, first oneself and by that means the conditions necessary for a world in which mankind can live. Self-knowledge is the prerequisite without which neither individuals nor nations will 
find the way to live at peace with themselves and each other. The utopian vision, delivered to a humble driver of the enemy forces is contained in the words "So mag es, in der Zukunft, Menschen geben, die ihren Sieg in Leben umzuwandeln wissen" ( $\mathrm{K}$. 132).

At the beginning of the narrative Kassandra sits on the cart that has brought her as Agamemnon's captive to the gates of Mycenae, where Klytaimnestra and death await them. This is the inevitable end of the way she has taken, that she has known all along, and one look into Klytaimnestra's eyes has confirmed it. It has been Kassandra's deliberate choice. Nevertheless the consequences fill her with fear, to combat which she asserts the discipline she has learned as princess, priestess, and outsider: "Jetzt kann ich brauchen, was ich lebenslang geübt: meine Gefühle durch Denken besiegen. Die Liebe früher, jetzt die Angst" (K. 11). Freed from all further conflict of choice, her curiosity - the curiosity of a professional observer - is directed towards herself, and the question which she recognizes as the key to understanding what has brought her to this end soon formulates itself: "Warum wollte ich die Sehergabe unbedingt?" (K. 6 \& 11). In the time left her till the soldiers come for her she seeks the answer, reflecting on her memories and the experiences that gradually led her from being merely a priestess and interpreter of dreams to being a seer, albeit one whose vision is intolerable to her own people. In the process the concepts of "sehen" and its opposite "blind sein" establish themselves as the polarities around which the thematic and narrative concerns of the text are clustered.

Kassandra, as a girl Priamos's favourite daughter, identifies initially wholly with her family and naively equates the wishes and decisions of the Palace with the well-being of Troy. Her desire to become a priestess she recognizes to have been at first motivated by a desire for power, born of frustration and a sense of lacking control when information about palace intrigues is denied her.

Jemand, der so getäuscht worden war wie ich, war denen nichts mehr schuldig. Ich hätte, vor allen anderen, ein Anrecht gehabt, zu wissen. Um sie zu strafen, mußte ich in Zukunft mehr wissen als sie. Priesterin werden, um Macht zu gewinnen? (K. 60)

Gradually however, her growing insight into the character of her father and brothers and the implications of their actions brings her into conflict with her family loyalties and consequently with her own sense of self. While she persists in partial blindness "[ . . . ] immer habe ich mir diese Zeiten von Teilblindheit gegönnt. Auf einmal sehend werden - das hätte mich zerstört" (K. 47) - ultimately, she confronts the fear that 
accompanies the asking of questions that shake the very ground of her being. Only then is she able to act in harmony with her vision.

Priamos, on the other hand, and through him Troy, voluntarily blind themselves in the name of honour and bring about their own destruction. The heroes of Troy are but the necessary pawns in a war which is really about power and wealth, like Kassandra herself "Objekt[e] fremder Zwecke". 5 They are however accessories to their own manipulation, since the honourable cause which serves to make valiant soldiers out of gentle men, brilliant heroes ready to lay down their life for Troy, is a deception, and they know it, for Helena does not exist. Paris, an inexperienced youth, "seiner selbst nicht inne" (K. 52), lost her to the King of Egypt on the journey home. But the Palace chooses to let the people believe she is there, because only a matter of honour is sufficient to rouse the people to enthusiasm for war:

Wir haben ja dann alle den Anlaß für den Krieg vergessen. Nach der Krise im dritten Jahr hörten auch die Kriegsleute auf, den Anblick der schönen Helena zu fordern [. . . ] Sie ließen von Helena ab und wehrten sich ihrer Haut. Um aber dem Krieg zujubeln zu können, hatten sie diesen Namen gebraucht. Er erhob sie über sich hinaus. (K. 78)

The phantom Helena is the personification of a moral code that has been lost. In Priamos's claim, "Es geht doch um die Ehre unsres Hauses"(K. 81), honour is reduced to a formula that has no basis in reality.

The necessary condition for the acceptance of such a deception is, however, a kind of blindness: the willingness to be deceived, which is rooted in an inherent tendency to self-deception. That this condition is given in Troy is evident in Kassandra's accounts of the earlier expeditions to Greece and the myths that surround them. The first "bescheidene Schiffchen" sent to consult the Delphic oracle became in the accounts of the palace historians "ein mächtiges Schiff" and the people were content to permit this distortion of their memories and to believe that the ambiguous outcome of it was in fact a glorious success. The pattern is repeated with the second ship, in which the disaster of Paris's expedition is prefigured: the ship was dispatched on a mission of honour, namely to bring back the King's sister Hesione, abducted some time before by the Spartan, Telemon. "Ein König, der seine entführte Schwester nicht zurückzugewinnen suche, verliere sein Gesicht" (K. 42). Yet Telemon has since made Hesione his wife and she lives as a free woman in Sparta. Only Hekabe faces the truth: that Hesione has no desire to return.

Kassandra attributes the willingness of the people on this occasion to acclaim 
Priamos's undertaking to the unrealistic longing for a lost Golden Age of Troy, and sees their subsequent blaming of this expedition for later unhappy events as a reluctance to see the truth of their own self-deception: "Um die unheimliche Wirklichkeit hinter der glanzvollen Fassade nicht sehn zu müssen, veränderten wir flugs unsre Fehlurteile" (K. 43). Thus misled by their own wishful thinking, the people call to the soldiers on the departing ship the ritualistic words that invoke the sense of wounded honour necessary to make heroes of them: "Die Königsschwester oder den Tod!" (K. 42) Again Hekabe's comments after the failure of the mission point to the underlying motivation for the undertaking. Priamos's vain desire for power and status:

Dein Vater, hat sie mir gesagt, will alles. Und alles gleichzeitig. Die Griechen sollen dafür zahlen, daß sie ihre Waren durch unsern Hellespont befördern dürfen: richtig. Sie sollen König Priamos dafür achten: falsch. Daß sie über ihn lachen, wenn sie sich überlegen glauben - was kränkt es ihn. Solln sie lachen, wenn sie zahlen. (K. 48)

That Priamos feels insecure in his position of power and authority, which rests more in his being "der Mann der idealen Königin" (K. 17) than in his own gifts, is evident in the story of Paris. At the birth of Paris, two varying interpretations of a dream of Hekabe associated ill omen with the child: the one, from Kalchas, at that time the official palace seer, that this child would set the whole of Troy alight; the other, that the child was destined to restore the snake goddess to her rightful place as keeper of the fire in each house. While the former interpretation might have seemed reason enough to do away with the child, as indeed Priamos was advised, it was in fact the latter interpretation which more influenced his thinking.

Schon einmal habe es im Palast eine Weiberintrige gegeben, damals vor des Paris Geburt. Die einen hätten ihn beschworen, das gefährliche Kind beiseite zu schaffen, die andern, natürlich Hekabe dabei, wollten gerade diesen Sohn als zu Höherem auserwählt retten. Zu Höherem! Also zum Anwärter auf den Thron des Vaters, was denn sonst. (K. 58)

Whether Paris were to have pretensions to the throne himself or to be the instrument for the restoration of a matriarchal order in religion and state is of little moment. In either case Priamos saw in Paris a threat to his position and elected to have the baby disposed of . But on Paris's unexpected reappearance he has more to gain by the aura of wonder that surrounds the young man than from his death and the threat to Troy is shrugged off: "Lieber mag Troia fallen, als daß mein wunderbarer Sohn sterben sollte" 
(K. 59). Paris himself is motivated by similar passions, determined to have Helen, not because he loves the as yet unseen beauty but "weil er durch ihren Besitz der erste aller Männer werde" (K. 67). Despite the violation of the old-established tradition of "Gastrecht" Priamos gives way to Paris's leaping ambition, because he can use it in a propaganda action by which he hopes to restore his reputation.

Helena. Der Name traf uns wie ein Stoß. Die schöne Helena. Darunter tat es der kleine Bruder nicht. Man hätte es wissen können. Man hatte es gewußt. Ich war Zeugin, wie im Hin und Her zwischen dem Palast und den Tempelpriestern, in Tag- und Nachtsitzungen des Rats eine Nachricht hergestellt wurde, hart, gehämmert, glatt wie eine Lanze: Paris der Troerheld habe auf Geheiß unsrer lieben Göttin Aphrodite Helena, die schönste Frau Griechenlands, den großmäuligen

Griechen entführt und so die Demütigung gelöscht, die unserm mächtigen König

Priamos einst durch den Raub seiner Schwester angetan worden war. (K. 74-5) Thus Helena too, if only in name, becomes an "Objekt fremder Zwecke", for the events that follow, while apparently linked by cause and effect, in fact serve to conceal the real motivation of those who set them in motion. However, it is the thoughtlessness with which Priamos and the Trojans, in the interests of a figment, honour, dispense with time-honoured customs in which Trojan society is rooted - in this case the "Gastrecht" - that is seen as crucial to the moral breakdown of which the ultimate sacking of Troy is the physical correlative. Kassandra describes her father as a king, "der es nicht ganz genau nahm mit der Wirklichkeit. Der in Phantasiewelten leben konnte; nicht ganz scharf die Bedingungen ins Auge faßte, die seinen Staat zusammenhielten, auch die nicht, die ihn bedrohten" (K. 16).

Wolf speculates in the Voraussetzungen that Troy may have been caught up in an unavoidable shift in the spheres of influence in the Mediterranean, that the peace-loving trading Minoans were losing ground to the aggressive warrior Greeks. "Eine Friedensordnung im östlichen Mittelmeer, die von den Achaiern zerstört wurde? Dies würde Kassandra in die Lage versetzen, sich von einer nicht mehr gültigen Utopie trennen zu müssen und keinen realen Lebens-Ort zu finden"( $V$. 104). And indeed, the text shows Troy in such a transitional period. Kassandra, trying to discover when the inevitable drift into war began - "Wann Krieg beginnt, das kann man wissen, aber wann beginnt der Vorkrieg?" (K. 76) - recognizes that changes have taken place in Trojan society, and speaks of "eine neue Zeit"; the longing of the Trojans for a lost Golden Age has been mentioned above. The loss of security and clear sense of identity associated with changing times is apparent in the religious observances of the nation, 
e.g. Kassandra's lifetime has seen the cessation of the sacrificial offerings of young boys at the altar of Apollo (cf K. 40 f.). To achieve this, a foreigner, the Greek priest Panthoos, from the temple at Delphi, had been the necessary agent. It was apparentiy a step forward to a more humane form of religion, but at the same time it was unwelcome evidence that Priamos acknowledged the superiority of the Delphic oracle in matters concerning Apollo (K. 39) and it later gave rise to the fear that it had been part of a treacherous plan to weaken the Trojans' defences. Even the supremacy of the god Apollo does not receive total support from the citizens. Women in particular, clustered around the earth-mother figure of Arisbe, once mistress of the King and mother of one of his sons, form a "Gegenwelt" (K. 56), living a life outside the city walls on the slopes and in the caves of $\mathrm{Mt} \mathrm{Ida,} \mathrm{following} \mathrm{practices} \mathrm{of} \mathrm{worship} \mathrm{no} \mathrm{longer} \mathrm{approved} \mathrm{of}$ by the state. Even the Queen goes secretly to consult with Arisbe when deeply troubled. In the midst of the war they live untouched by the rule of the Palace and its security agents: "Bis hierher reichte die Zitadelle nicht. Sie konnten nicht zugleich den Feind und uns bekämpfen" (K. 149).

"Die neue Zeit" is embodied above all in the figure of Eumelos, the head of the palace security guard.

Ich brauchte eine Weile, bis ich sie [die neue Zeit] begriff. Sie war schon in der Festung, eh der Gegner kam. Sie drang, ich weiß nicht wie, durch jede Ritze. Bei uns trug sie den Namen Eumelos. (K. 87)

Eumelos is described as "ein fähiger Mann am rechten Platz" (K. 64). By means of professed loyalty to the person of the King he subtly gains Priamos's trust and furthers his own career. In the term "Königspartei" used by his supporters of themselves lies the inference that there exists another group of people who are against the king. Thus, in reality, Priamos's latent fears for his own security of power are being exploited and reinforced. Once the hypothesis of threat is accepted, all the precautions, infringements of personal liberty and modifications of the old ways appear logical and necessary. In the same way the Trojans are tricked into believing in the necessity for war. It is finally Anchises, father of Aineias, who is able to explain to Kassandra, who is despairingly trying to understand why Eumelos always appears to be justified in what he does, the fault in the logic:

Nämlich: Er setzt voraus, was er erst schaffen mußte: Krieg. Ist er soweit gekommen, nimmt er diesen Krieg als das Normale und setzt voraus, aus inm führt nur ein Weg, der heißt: der Sieg. Dann allerdings diktiert der Feind, was dir zu tun bleibt. (K. 120) 
It is this "Denkfehler" on which the "Pflichten des deutschen Soldaten" are based. The sacrifice, the honour of the soldier are as empty of meaning, as much a phantom as Helena, being based on the assumption that war is necessary and normal. But once this assumption is accepted, a new hierarchy of values comes into force. The integrity of the individual, both in the sense of inner moral values and in the sense of the continued existence of a person's being may be sacrificed to the common goal, victory. In any conflict between a man's personal moral stance (or his own sense of honour) and the common cause, the latter must hold sway. In this case the "öffentliche Anerkennung" attainable by service and sacrifice must suffice as a substitute for the personal sense of honour. This applies to the nation and its code of values as well. In the case of Troy, as Anchises perceived, the need to be victorious means that the Trojans must become like the Greeks, sacrificing their own customs and code to those of the enemy.

Er [Eumelos] wollte uns, wie der Krieg uns brauchte. Wir sollten werden wie der Feind, um inn zu schlagen. Es lag uns nicht. Wir wollten sein wie wir, unkonsequent $[. .$.$] (K. 36)$

Even before the outbreak of the war this modelling process had begun: "Sprach in Troia irgendein Mensch von Krieg? Nein. Er wäre bestraft worden. In aller Unschuld und besten Gewissens bereiteten wir ihn vor. Sein erstes Zeichen: Wir richteten uns nach dem Feind. Wozu brauchten wir den?" (K. 74). To be like the Greeks means in time of war to train warriors, heroes after the model of Achilles. This necessarily has far-reaching consequences, not only for the men. The writers and singers of the Palace are hamessed to the propaganda machine whose aim is to glorify battle and the deeds of the warriors in order to make them believe not in their own experience but in the "Idealgestalten" they are portrayed as being.

Doch sah ich, wie die, die auf dem Schlachtfeld waren, die Lügen derer, die den

Kampf nicht kannten, allmählich glaubten, weil sie ihnen schmeichelten. (K. 91) Heroes are not born but created, are objects to be manipulated to achieve a desired end. Even "Hektor, dunkle Wolke", principal hero of the Trojans is portrayed as a victim of the grim necessity of the war machine. His wife Andromache pleads for Kassandra's help to prevent this happening: "Er sei doch nicht der Mensch, aus dem man Helden macht" (K. 103). But neither Kassandra nor Hekabe can prevent it, for "sie bauten ihn zum Ersten Helden auf" (K. 103). He too accepts his fate as necessary and begins to prepare for his own destruction: "[. . ] bewundernd haben wir alle mit angesehen, wie er sich dann, ganz gegen seine Neigung, für den Krieg trainierte" (K. 66). 
The men become moulded by the logic of war, bound by the seemingly inevitable chain of action and reaction, of victory and defeat. The death of Patroklos releases in Achilies the fury of revenge which results in the death of Hektor. His acts of revenge provoke the Trojans in turn. It is only the bodily intervention of Kassandra that prevents the slaughter of Greek prisoners in revenge for the Trojans sacrificed by Achilles on Patroklos's funeral pyre. The authority of her person as priestess reminds the avenging Trojans that "an eye for an eye" is not the Trojan way (cf. K. 129f.). But she is unable to stem the tide which swamps Trojan customs and beliefs with the new moral code dictated by the war. The more hopeless Troy's position becomes, the more "ruhmredig, marktschreierisch und speichelleckerisch" (K. 115) the texts of the singers become. To the need of the moment is sacrificed the very foundation of Trojan religious beliefs: the priests are instructed to honour no longer the dead heroes but the living ones. "Ich war betroffen. Auf der Verehrung der toten Helden beruhte unser Glauben, unser Selbstgefühl" (K. 115) says Kassandra and wonders "War es nicht wichtiger, nach unsrer Art, nach unserem Gesetz zu leben, als überhaupt zu leben?" (K. 117). War becomes not just the means to an end but the end in itself, suspending any other reality.

Denn es ging doch nicht an, so dachte ich, den ganzen Krieg und unser ganzes Leben - denn war der Krieg nicht unser Leben! - auf den Zufall einer Lüge aufzubauen. Es war doch ausgeschlossen, so dachte ich, [. . . ] daß die reiche Fülle unsres Daseins auf eine störrische Behauptung gemindert werden sollte. Wir mußten uns doch bloß auf unsere troische Tradition besinnen. Wie war die aber? Worin bestand die doch? Bis ich begriff: In Helena, die wir erfanden, verteidigten wir alles, was wir nicht mehr hatten. Was wir aber, je mehr es schwand, für um so wirklicher erklären mußten. (K. 97)

The undermining of Trojan society by the imposition of the new code is felt most acutely by Kassandra in the breakdown of normal relationships between men and women. The men, increasingly desensitized by their battlefield experiences, use the women in the same way they themselves are used, as objects and victims. When Achilles, first hero of the Greeks, astounded and threatened to find himself challenged by a woman in battle, rapes Penthesilea after killing her, it is as much the implications of that act for all women as the revulsion at the deed of this one enemy that fills the women of Troy with horror.

Der Mann, unfähig, die Lebendige zu lieben, wirft sich, weiter tötend, auf das 
Opfer. Und ich stöhne. Warum. Sie hat es nicht gefühlt. Wir fühlten es, wir Frauen alle. Was soll werden, wenn das um sich greift. Die Männer, schwach, zu Siegern hochgeputscht, brauchen, um sich überhaupt noch zu empfinden, uns als Opfer. Was soll da werden. (K. 137)

Nevertheless, the treatment of the figure of Achilles in Christa Wolf's adaptation of the traditional material is in itself one of the text's most striking features. The "Verfremdungseffekt" achieved by the association of the epithet "das Vieh" with the name of the greatest of the Greek heroes is one of the principal means by which a re-evalution of the concept of hero is achieved. "Achill, das Vieh" is mentioned several times before ever the details of his "heroic" deeds are recounted. Thus the reader's reception of Achilles is programmed in advance. The deeds of Achilles are exposed as the acts of a man unable to accept his sexual identity. Homosexual by preference, he feels obliged to prove his manliness in the pursuit of women and prowess on the battlefield.

Achill stellte nämlich allen nach: Jünglingen, nach denen ihn wirklich verlangte, und Mädchen, als Beweis, daß er wie alle war. Im Kampf ein Unhold, damit jeder sah, daß er nicht feige war, wußte er nichts mit sich anzufangen nach der Schlacht. (K. 95)

The slaying of Troilos, and the defeat of Polyxena and Hektor are, seen from the point of view of the Trojans, not acts of great bravery which help bring about an important victory, but brutish deeds, inspiring awe and horror at the indifference they reveal towards human dignity or even the gods honoured by Greeks and Trojans alike.

"Was soll da werden", asks Kassandra. Indeed, as the war proceeds, the women of Troy learn to fear not only the Greeks, but their own men as well: "Wenn man es recht betrachtete - nur traute niemand sich, es so zu sehn -, schienen die Männer beider Seiten verbündet gegen unsre Frauen" (K. 119). Polyxena, Kassandra's sister, and Kassandra herself, are both used as objects of barter. Kassandra, while indifferent to her fate in being married off to Eurypylos in return for the support of the latter's army, recognizes that that act must do irreparable harm to Troy's cause, since it will inevitably plunge the women of Troy into conflict: they must either turn against themselves or against Troy.

Nie war in Troia eine Tochter eines freien Mannes zur Ehe gezwungen worden. Dies war das Letzte. Als der Vater nach Eurypylos und seinem Heer von Mysern schickte, obwohl bekannt war, der wollte mich als Lohn zur Frau, da konnte jeder wissen: Troia war verloren. Nun war in mich, in Hekabe die Königin, in die unglückliche Polyxena, in alle Schwestern, ja in alle Frauen Troias der Zwiespalí 
gelegt, daß sie Troia hassen mußten, dessen Sieg sie wünschten. (K. 90) Polyxena, indeed, turns against herself, allowing herself to be used as "Lockvogel" to lure Achilles to a treacherous tryst in the temple, where he is killed by Paris. Again in terms of the war the need is obvious and the plan persuasive. But it is her father's impatient words "Um sie geht es nicht. Es geht uns um Achill" that make Kassandra see at last that the sense of honour and justice of the war-makers can never be compatible with her own, or Polyxena's.

Hastig, unheimlich schnell erwog ich, daß sie im Recht sein könnten. Was heißt im Recht. Daß das Recht - Polyxenas Recht, mein Recht - gar nicht zur Sprache stand, weil eine Pflicht, die, unsren schlimmsten Feind zu töten, das Recht verschlang [...]

Ich sagte: Nein. (K. 144)

In rejecting the proposal to sacrifice Polyxena she is rejecting the assumption that any duty is greater than the duty to preserve one's moral integrity.

Central to the narrative is Kassandra's first public "Anfall" and prognostication of doom. It is significant that its occasion is an event in which the factors of lust for power, the breaking with time-honoured custom and the machinations of Eumelos are in conjunction, and that its immediate consequence is a crisis of identity. At the farewell dinner in honour of Menalaos, King of Sparta, to whom all state honours are due, but who is now denied the title of "Gastfreund" at the instigation of Eumelos, Paris, whose ambitions are supported by Eumelos, in defiance of his mother's reprimand lays public claim to the right to be the one to bring back Hesione, or if not her, a more beautiful woman in her stead. This can be none other than Menelaos's wife, Helena:

Nie vorher herrschte im Palast von Troia solche Stille. Ein jeder spürte, ein Maß, das bisher gültig war, wurde hier verletzt. So hatte nie ein Mitglied unserer Familie sprechen dürfen. Ich aber. Ich allein sah [. . . ]: Was in dieser Stunde seinen Ausgang nahm, war unser Untergang. (K. 68)

The sense of total alienation and the period of "geistige Umnachtung" that accompany and follow this and other such attacks are an indication of the significance the experience of "sehen" has for her personally. In allowing the voice that comes from deep within her to speak Kassandra has for the first time allowed the ever-deepening conflict between her loyalty to her family, in particular to her father, and her knowledge of what is right to surface. The madness that befalls her signifies the end of 
her silence and the end of the self-deceiving pretence of wanting the same thing as the Palace and Eumelos - "Wahn-Sinn als Ende der Verstellungsqual" (K. 69) - but it also serves as a means of avoiding the full implications and consequences of the event. This "time out" is essential, since Kassandra is not yet ready or able to tread her new path with consistency: "Ich war auf mich zurückgefallen. Doch es gab mich nicht" (K. 69). The way she must take, in order to find a self, prompted and guided by Arisbe and Anchises, is one of looking inward, of gradually acknowledging the consequences of her vision for herself. That is, primarily, having to accept a degree of responsibility for the state of affairs in Troy, even if unwillingly at first.

Wieso hast du sie stark werden lassen. [asks Arisbe]

Die Frage verstand ich nicht. Der Teil von mir, der wieder aß und trank, sich wieder "ich" nannte, verstand die Frage nicht. Jener andre Teil, der im Wahnsinn geherrscht hatte, den "ich" nun niederhielt, wurde nicht mehr gefragt. Nicht ohne Bedauern ließ ich den Wahnsinn los, nicht ohne Befremden sah mein inneres Auge eine unbekannte Gestalt aus den dunklen Wassern auftauchen, die sich verliefen. (K. 72)

While seeing more than her fellow citizens, Kassandra is subject as they are to the blindness of self-deception, the fear of acknowledging the truth. Even the voice from within her, which is irresistible in its insistence on being heard, proclaims the doom of the nation in words which avoid directness. Subconsciously, she must protect herself from consequences with which she could not yet cope. To have spoken the whole truth would have meant the loss of the love of her father.

Denn warum schrie ich, wenn ich schrie: Wir sind verloren! Warum nicht: Troer, es gibt keine Helena! Ich weiß es, wußte es auch damals schon: Der Eumelos in mir verbot es mir [...] lch, Seherin, gehörte zum Palast. (K. 79)

For the same reason she avoids seeking out or joining those who belong to the "Gegenwelt", despite the glimpses she has had of it and her underlying envy of those who belong to it. "Da warnte etwas mich, nämlich die geheime Angst, unvorbereitet einen Blick in eure Welt zu tun. Lieber litt ich, blieb aber, wo ich war" (K. 98).

It is a fear very similar to that of the narrator in Kindheitsmuster. The fear of what may be discovered and of the consequences of that is balanced against the "Gier nach Erkenntnis". Heinz-Dieter Weber describes the writing process in Kindheitsmuster thus: "Die Reflexionen über das Gedächtnis, über Erinnern und Vergessen haben gewiß zunächst eine individualethische Pointe. Es ist der Mensch, der sich erinnert, nicht das Gedächtnis. Aber diese für sein Wirklichkeitsverständnis zentrale moralische Leistung 
des Menschen erscheint zugleich als bedingt und bedroht durch eine ihm nicht verfügbare Macht: die Angst". ${ }^{6}$ Kassandra pursues her memories, in a similar way to the narrator of Kindheitsmuster, out of a desire for self-knowledge which stems from a moral imperative as much as from curiosity. While awaiting her imminent death she marvels at her own rigour in her pursuit of the truth about herself: "Wohin ich blicke oder denke, kein Gott, kein Urteil, nur ich selbst. Wer macht mein Urteil über mich bis in den Tod, bis über inn hinaus, so streng" (K. 27f.). The "Angst" she encounters again and again is the anxiety that accompanies self-appraisal, the fear of the strictest of judges, self, that has to be confronted if the capacity for "leben" and "sehen" is to be realized. This is the logic that underlies another passage in the text, where the association of ideas is only apparently one of chance:

Wer lebt, wird sehn. Mir kommt der Gedanke, insgeheim verfolge ich die Geschichte meiner Angst. Oder, richtiger, die Geschichte ihrer Entzügelung, noch genauer: ihrer Befreiung. (K. 41)

The blindness of people stems from the fear of the pain of seeing which makes them pursue paths that lead to self-annihilation rather than to life.

Wenn wir Ameisen wären: Das ganze blinde Volk stürzt sich in den Graben, ertränkt sich, bildet die Brücke für die wenigen Überlebenden, die der Kern des neuen Volkes sind. Ameisengleich gehn wir in jedes Feuer. Jedes Wasser. Jeden Strom von Blut. Nur um nicht sehn zu müssen. Was denn? Uns. (K. 49) ${ }^{7}$ In Kindheitsmuster the narrator recognizes the productivity of "Angst": "Die besondere Natur des Leidens, das "Angst" heißt, ist es, die jene Art von Produkten hervortreibt, in denen du dich erkennst. Wozu es leugnen". 8 Not to suffer this form of anxiety is not to see and hence not to live. "O daß sie nicht zu leben verstehn" says Kassandra pityingly of the victorious Greeks, who despite their victory will remain blind: "Mit Blindheit geschlagen, ja. Alles, was sie wissen müssen, wird sich vor ihren Augen abspielen, und sie werden nichts sehen" (K. 10).

"Leben" is the alternative sought by those who belong to the "Gegenwelt". "Zwischen Töten und Sterben ist ein Drittes: Leben" says a young slave-girl who has fled from Achilles's service. By living outside the walls of the beleaguered city they at least partially and temporarily escape the artificial reality imposed by the state of war which allows only two choices, to kill or to die. Existing in a "Zeitloch", and in the knowledge that their time is limited, they live with an intensity and consciousness that makes them aware as never before of the intrinsic value in all the variety of human activities: eating, sharing, learning, healing, touching, creating, laughing and 
worshipping.

The objects of worship here are not the gods of the city temples. They are female figures to whom the worshippers ascribe a variety of names. One name, Kybele, familiar to Kassandra since childhood, has till now been shrouded in mystery and associated with the king's suspicion of female intrigues. Now, in a conversation with Arisbe, this worship is demysticised and secularized. The stone images represent not a divinity, according to Arisbe, but stand "für das, was wir in uns nicht zu erkennen wagen" (K. 140). They offer therefore an indirect means of encountering the self and as such represent a positive life force, while the gods of the city temples, whose priests are in the service of the Palace, must be seen as mere instruments in the further self-deception of those who will not see.

Nevertheless, the alternative life on the Ida-Berg does not give its participants immunity from the fate of Troy. Christa Wolf's suggestion in the Voraussetzungen that Kassandra is fated, "keinen realen Lebens-Ort zu finden", might suggest a wholly pessimistic interpretation, another Kein Ort. Nirgends, epecially as the end of the narrative offers no hope: "Gegen eine Zeit, die Helden braucht, richten wir nichts aus" are amongst Kassandra's last words. The inference of the context is that the regime of "die neuen Herren" has no foreseeable end. Yet against this pessimism might be held a further ironic twist. At a moment of despair, Kassandra has contemplated throwing herself at Klytaimnestra's feet to beg that she might live and be allowed to pass on her story to another woman:

Verfüge, daß sie, was sie von mir hört, ihrer Tochter weitersagen darf. Die wieder ihrer Tochter, und so fort. So daß neben dem Strom der Heldenlieder dies winzige Rinnsal, mühsam, jene fernen, vielleicht glücklicheren Menschen, die einst leben werden, auch erreichte. (K. 93)

Though she then rejected this possibility, Kassandra has indeed found a narrator, who has succeeded in singing a different song from the strident tones of the Heldenlieder, one in a minor key, and who has succeeded in finding the missing signs whose absence from the official records is lamented by Kassandra:

Die Täfelchen der Schreiber, die in Troias Feuer härteten, überliefern die Buchführung des Palastes, Getreide, Krüge, Waffen, Gefangene. Für Schmerz, Glück, Liebe gibt es keine Zeichen. (K. 89)

In so doing Wolf has not only given us cause to question the ethical and aesthetic assumptions behind a long literary tradition, but, if we choose to read the text as a parable for our times, has shown that if the concept of honour is to have meaning today, 
it can only be by restoring to it the "geistige Komponente" which according to $E$. R. Curtius's analysis ${ }^{9}$ was seen by Homer himself as essential to the ideal hero. Without that component, whether we call it "Weisheit" or "Tugend" or "Selbstkenntnis", the concept of honour may be all too easily reduced to "Soldatenehre" and exploited for ends which must inevitably lead to self-destruction, whether for Troy or for humanity.

\section{Footnotes}

1 Christa Wolf, Kassandra, Darmstadt 1983. Hereafter quoted as K. with page number.

2 Hermann Pongs, "Soldatische Ehre in der Dichtung der Gegenwart", Dichtung und Volkstum. NF des Euphorion 42,2 (1942), p. 89.

3 Friedrich Maurer, "Zum ritterlichen Tugendsystem", DVjs 24 (1950), p. 527.

4 Christa Wolf, Voraussetzungen einer Erzählung: Kassandra, Darmstadt 1983, p. 117. Hereafter quoted as $\mathrm{V}$. with page number.

5 Christa Wolf refers to Kassandra as "Objekt fremder Zwecke" in the first lecture of the Voraussetzungen (cf. V. 10).

6 Heinz-Dieter Weber, Über Christa Wolfs Schreibart, Konstanz 1984, p. 44.

7 The use of "wir" in the text is worthy of note. On the level of Kassandra's personal story it is one of the markers indicating her progress towards "Erkenntnis", in that it denotes the group with whom she identifies at any point; eg. on one occasion it marks her first shock of understanding that the nature of the Greeks, the enemy, is not strange to her: "Sie sind wie wir!" (K. 16); or at another stage it shows her doubt about where her loyalty should be: "Sie" sagte ich von den Leuten um Anchises, nicht "wir", wir zu sagen war mir noch nicht erlaubt. Schwankend und gebrechlich und diffus war das "Wir", das ich, solange es nur ging, benutzte. Es schloß den Vater ein, aber schloß es mich noch ein?" (K. 108); and finally, when she achieves understanding with Arisbe: "Es gibt Zeitenlöcher. Dies ist so eines, hier und jetzt. Wir dürfen es nicht ungenutzt vergehen lassen.

$\mathrm{Da}$, endlich, hatte ich mein 'Wir'". (K. 141)

But on another level, that of the reflecting "ich" of the narrative framework to the text, it is used to mark her sense of identity with the experience of all human beings, whether it be their faulty sense of justice (cf.p. 135) or their capacity to do horrific things (cf. p. 135) or their fear of "seeing", as here (p. 49). Thus the "wir" is used to universalize Kassandra's experience and facilitates the reading of the text as a parable.

8 Christa Wolf, Kindheitsmuster, Berlin 1962, p. 462.

9 Cf. Ernst Robert Curtius, Europäische Literatur und lateinisches Mittelalter, Bern 1948, p. 179. 